\title{
STATE COURT INTERPRETATION OF FOREIGN LAW: A GUIDE FOR THE FEDERAL COURTS
}

The application of foreign law is at best a difficult matter; at times it may present problems sufficiently subtle that they are more easily ignored than solved. In Mason v. American Emery Wheel Works, ${ }^{1}$ the plaintiff, a citizen of Mississippi, was injured in Mississippi by the shattering of an emery wheel manufactured for his employer by the defendant, a Rhode Island Corporation. The action was brought in the United States District Court for Rhode Tsland, which, applying the law of Mississippi, dismissed the complaint. Authority for the dismissal was a 1928 Mississippi Supreme Court decision holding that such an action was precluded by the lack of privity between the manufacturer and the distant user of goods. ${ }^{2}$ But the Court of Appeals for the First Circuit reversed on the ground that a recent dictum in a Mississippi Supreme Court opinion $^{3}$ indicated willingness on the part of that court to reconsider its 1928 holding and follow the modern doctrine of manufacturer's liability enunciated in MacPherson v. Buick Motor Co. ${ }^{4}$

The final disposition of the case ${ }^{5}$ is not as interesting as the doctrine under

1241 F.2d 906 (C.A.1st, 1957), cert. denied 355 U.S. 815 (1957).

2 Ford Motor Co. v. Myers, 151 Miss. 73, 117 So. 362 (1928).

${ }^{3}$ E. I. Du Pont de Nemours \& Co. v. Ladner, 221 Miss. 378, 73 So.2d 249 (1954).

4217 N.Y. 382, 111 N.E. 1050 (1916).

${ }^{5}$ There may be doubt whether a fair reading of the later dictum seriously indicates a reversal of opinion by the Mississippi Supreme Court. The issue in the Du Pont case, 221 Miss. 378, 400-1, 73 So.2d 249, 255 (1954), in which the critical dictum is found, was whether the manufacturer's negligence was the proximate cause of injury in view of the warning given to the plaintiff's seller that the goods were definitely dangerous. The court expressly excluded decision of all issues except proximate cause-even the issue of whether there would have been liability had the proximate cause been present.

The critical dictum itself is addressed to none of the major issues in the case. It can be read as simply establishing that a damage to property will be actionable where a similarly caused personal injury would be.

"Whatever the rule may have been originally, the principle seems now to be well estabished by the decisions of many courts that a person who has had no direct contractual relations with a manufacturer may nevertheless recover from such manufacturer . . . in the same manner that such a remote vendee or other third person can recover for personal injuries." Id., at 399 and 254.

Even on the question of manufacturer's liability the court indicated that the issue would be whether the narrower rule of its own imposing liability on manufacturers of food for human consumption should be extended to cover animal food, id., at 400 and 255, and not whether the general doctrine of MacPherson v. Buick Motor Co. should be accepted. In fact the Mississippi court never mentioned the MacPherson case nor did it make any mention of Ford Motor Co. v. Myers, 151 Miss. 73, 117 So. 362 (1928), the case in which it rejected the MacPherson doctrine.

In addition to this the plaintiff in the Mason case was not the distant purchaser of the goods but an employee of the distant purchaser, and the finding of liability required not merely an acceptance of the MacPherson doctrine, but an extension of it. It may be that it was the near universality of manufacturer's liability-that plaintiff could have recovered had practically any other law than Mississippi's been applicable-that accounts for the federal court's willingness to read Mississippi law the way it did. 
which it was justified. To the court no more was involved than an application of state law, entirely governed by the principles of Erie R. Co. v. Tompkins. That the law to be applied was foreign to the state in which the court sat had no influence upon the method of ascertaining that law; the court took upon itself the problem of interpretation presented by the Mississippi cases rather than referring to the law of Rhode Island for a guide to that interpretation.

In fact, the court never explicitly mentioned that it was applying the conflicts law of Rhode Island, but only that "the district court, no doubt correctly under now familiar authorities, deemed itself to be obliged to apply the Mississippi local law to determine the tort liability... ." And when considering the effect to be given to dictum, the court made no reference to any possible conflicts problem, but rather referred as authority to a note on the problem of a federal court ascertaining the directly applicable state law. ${ }^{8}$ Reference to the concurring opinion filed in the case confirms this interpretation of the majority opinion. In the view of the concurring judge, the court was correct in disregarding the old holding but "in doing so I realize that we present a difficult problem for district judges when they must apply the Erie doctrine to situations wherein the considerations as between conflicting holdings and dicta are not as clearly defined as they are here."

But the case is not simply one in which the federal court must interpret the law of the state in which it sits. The forum and the events which formed the basis of the action did not coincide. A choice of law problem was presented to the District Court of Rhode Island. Under Klaxon Co. v. Stentor Electric Mfg. Co. ${ }^{10}$ the federal court was bound to apply the conflict of law rules of the state in which it sat; and the force of Klaxon would seem to require that the state conflict of law rules which bound the federal court were not only choice of law rules but also those for ascertaining appropriate foreign law. Thus the critical question is not what the federal court could have done in the Erie situation, but what the Rhode Island court would have done in the conflicts situation.

But if it is Rhode Island law to which reference must be made, and if the federal court is only to act, in effect, as another court of Rhode Island, then the result is anomalous. For the result in the instant case is that a Rhode Island court would strain to interpret applicable Mississippi law so that a Mississippi plaintiff could recover from a Rhode Island corporation.

It may well be that a federal court sitting in Mississippi, could, in the desire to follow current notions of justice, so interpret the Mississippi law to find

6304 U.S. 64 (1938).

7 Mason v. American Emery Wheel Works, 241 F.2d 906, 907 (1957), cert. denied 355 U.S. 815 (1957).

${ }^{8}$ Id., at 909. The reference was to Hart and Wechsler, Note on the Ways of Ascertaining State Law, in The Federal Courts and the Federal System 628-30 (1953).

${ }^{9}$ Mason v. American Emery Wheel Works, 241 F.2d 906, 910 (1957) (concurring opinion). 10313 U.S. 487 (1941). 
manufacturer's liability. But it is quite another thing-and requires more than an examination of the foreign law-to find that a state court would reach the same result. What is called for is an analysis of the methods of state courts in dealing with unclear foreign law rather than an examination of the ways of federal courts in ascertaining state law.

\section{I}

Thus it has been said that the interpretation of applicable law might be different in the state than in the federal courts. This is aside from any problem which may arise because the federal courts may take judicial notice of state law while a particular state may still require pleading and proof of foreign law. ${ }^{10 \mathrm{a}}$ That is, throughout this comment it is assumed that all pertinent authorities of the appropriate law are before the court, either by judicial notice or by complete pleading and proof, and that those authorities, when presented, are unclear.

At first glance it is not then clear why the process of interpreting unclear law should be different depending upon whether the court is called federal or state. In the cases that have come up the federal and state tribunals have seemingly treated the problem in the same manner."11 Both look for expressions or data indicating how the case would be decided by the courts of the appropriate jurisdiction. A holding in point is the strongest indication of the applicable law in the federal12 well as as state courts. ${ }^{13}$ Similarly, after some battle it was decided that the holding of lower state courts was binding on the federal courts; ${ }^{14}$ just as the state forum will normally follow a holding from a lower court of a foreign jurisdiction. ${ }^{15}$

But this similarity is superficial; for the federal and state courts are governed

10a For a discussion of the problems arising under the pleading and proof requirement, see Currie, On the Displacement of the Law of the Forum, 58 Col. L. Rev. 964 (1958); Nussbaum, The Problem of Proving Foreign Law, 50 Yale L. J. 1018 (1941).

"In One court has explicitly stated that to it the problem was exactly the same. An Illinois appellate court, in deciding a suit against a Delaware corporation determined what the law of Delaware was by relying on a twenty-three year old decision of the Delaware Chancery Court. Its justification: "The decision of the Delaware Chancery Court in the Italo case was not appealed, and, although decided in 1934, so far as we can determine it is the only decision in that state on the precise question involved here. The Chancery Court of Delaware is at least equal to the Superior Court of that state, and the federal courts have held themselves bound by the decisions of the Superior Court where there is no showing that the decision was manifestly in error." Continental-Midwest Corp. v. Hotel Sherman, 13 ml.App.2d 188, 195-96, 141 N.E.2d 400, 404 (1957).

12 Erie R.Co. v. Tompkins, 304 U.S. 64, 78 (1938); and see Harnett and Thornton, Precedent in the Eerie-Tompkins Manner: A Decade in Retrospect, 24 N.Y.U.L.Q. Rev. 770, 778 (1949).

${ }^{13}$ E.g., Adler v. Dickstein, 139 Pa. Super. 447, 12 A.2d 489 (1940); White v. Woodmen of the World, 87 Utah 477,50 P.2d 422 (1935).

${ }^{14}$ West v. American Tel. \& Tel. Co., 311 U.S. 223 (1940). See also, Fidelity Union Trust v. Field, 311 U.S. 169 (1940).

${ }^{15}$ E.g., Moscov v. Mutual Life Insurance Co. of New York, 387 Ill. 378, 388-89, 56 N.E.2d 399,404 (1944). 
by basically different capacities and limits when ascertaining applicable law. There is no federal substantive law of the forum when the federal court is the forum in a diversity suit; nor is the federal court involved in a choice of law problem. That there is no such law of the forum follows from the theoretical underpinnings of Erie R. Co. v. Tompkins in which the Supreme Court swallowed whole Holmes' theory of what the "law" to be applied was-only that which had the authority of a sovereign state behind it. ${ }^{16}$ Thus there is no place elsecertainly not to its own jurisdiction-that the federal court can go but the laws of the state.

In the same sweep the Court has taken the choice out of the choice of law problem. Though frequently diversity cases will involve pertinent facts relevant to more than one jurisdiction only mechanical directions lead to which jurisdiction is to be looked to. The command of the Supreme Court to the federal courts is clear: apply the law of the state in which you sit; and if any other law must be applied it is to be chosen by the law of the state in which you sit..17

In a state court, on the other hand, there are no strict commands imposed by the Supreme Court. Within the bounds of the Due Process and Full Faith and Credit Clauses the state court can treat a choice of law problem in its own manner; all the historic conflicts' devices for arriving at the result one wants to arrive at are present as they cannot be in the federal courts. And furthermore, the fact that a state court may have an interest in the outcome of the litigation, while the federal court has no interest in the result of any particular diversity suit, may give the state court a greater motivation for exercising the full range of its alternatives.

\section{II}

If there may be a substantial difference in the way a federal court acting independently will interpret foreign law and the way a state court would make that interpretation, then the critical question is: how is a federal court applying state conflict of law rules to know what interpretation of foreign law would have been made by the state court. That is, is there any more involved than the federal court guessing what the state court would do, or can past experience show that there are some guides to how the state court will behave? It is the thesis of this comment that there is some predictable standard of behavior for state courts in their interpretation of foreign law. The remainder of the comment first, discusses this standard of behavior; and second, examines a case where a court indicated its responsibility to follow such behavior.

The factors influencing the manner in which state courts may treat unclear

${ }^{16}$ Erie R.Co. v. Tompkins, 304 U.S. 64, 79 (1938). For the classic statements by Holmes, see Black and White Taxicab Co. v. Brown and Yellow Taxicab Co., 276 U.S. 518, 533-35 (1928) (dissenting opinion); Kuhn v. Fairmont Coal Co., 215 U.S. 349, 372 (1909) (dissenting opinion).

${ }^{7}$ Klaxon Co. v. Stentor Electric Mfg. Co., 313 U.S. 487 (1941). 
foreign law are aptly illustrated by the cases below. In Bostrom v. Jennings, ${ }^{18}$ the Michigan Supreme Court pleaded the lack of clarity of appropriate foreign law to justify an effective denial of one of the most sacred black letter guides of the conflict of laws-that the law of the place of a tort determines liability for the tort. ${ }^{19}$

The parties, both residents of Michigan, were driving through Illinois engaged in a joint venture when the tort occurred. The issue was whether the negligence of one joint venturer was imputable to the other in a tort suit between them. Admittedly there are rational grounds on which the Michigan court might have decided to determine this according to Michigan law. ${ }^{20}$ Nevertheless the imagination of the Michigan court was not up to so bold a step; it was quite certain the law of Illinois, the place of the tort, was the proper law to apply. But on examining that law the court faced unexpected confusion. To the Michigan court the Illinois Supreme Court had never spoken on the issue; and as for the lower Illinois courts, while they had spoken, their language changed with the occasion and was never addressed to the issue before them. ${ }^{21}$ To reach such a conclusion though, the Michigan court had cavalierly to dismiss the strong language of an Illinois Appellate Court, in reference to a suit between joint venturers, that: "... if the persons riding in the automobile were engaged at the time of the accident in a joint enterprise... plaintiff could not recover."22

The Michigan Supreme Court, after characterizing this pronouncement as a dictum, then invoked its own principle that

when a tort action brought in this State is governed by the common or unwritten law of another State and the latter has not been declared by its courts of last resort with absolute certainty, we determine the rights of the parties according to the lex fori. ${ }^{2}$

The law of the forum, as announced by the instant case, was that the negligence of one joint venturer would not be imputed to be the other in a tort

18326 Mich. 146, 40 N.W.2d 97 (1949).

19 "[T] he law of the place of the wrong determines whether or not there is a cause of action for the wrong. This is true although both parties are elsewhere domiciled." 2 Beale, The Conflict of Laws 1289-90 (1935). See also, 15 C.J.S., Conflict of Laws \$12(a)(1) (1939).

${ }^{20}$ For both parties are domiciliaries of the forum, and the only contested issue is the interpretation of a relationship which began in the forum. See Morris, The Proper Law of A Tort, 64 Harv. L. Rev. 881, 885-86 (1951), where the following hypothetical case is discussed: "(4) that $P$ is a guest occupant, a resident of $F$, who was offered a ride in $F$.... It seems at least arguable that in (4) also we should reach more sensible results by applying the law of $\mathrm{F}$ rather than the law of $\mathrm{X}$, since all the significant factors are $\mathrm{F}$ factors except the fortuitous place of the harm."

${ }^{21}$ Cases discussed by the court were Brooks v. Snyder, 302 Ill. App. 432, 24 N.E.2d 55 (1939); Barnett v. Levy, 213 Ill. App. 129 (1919); and Chicago, P. \& St.L. Ry. Co. v. Condom, 121 Ill. App. 440 (1905).

${ }_{22}$ Barnett v. Levy, 213 IIl. App. 129, 134 (1919).

${ }^{23}$ Bostrom v. Jennings, 326 Mich. 146, 154, 40 N.W.2d 97, 101 (1949). 
action between them. But the device of pointing to the uncertainty of foreign law to achieve a desired result was not used merely to satisfy general ideas of justice. All factors in this case pointed to Michigan as the appropriate and rational governing law. The parties were domiciliaries of the forum, and the relationship to be interpreted began in the forum. The court held that the policy of the forum was that that relationship would not be a bar to recovery. Against these factors stood only the fortuitous place of injury. Only to serve its own interests did the court circumvent the orthodox methods of interpretation and decision. ${ }^{23 a}$

But uncertainty can take many forms; and minus a holding precisely on point, it may, as shown by In re Palmer's Estate ${ }^{24}$ be found where the inquiring court wishes to find it. Respondents, claimants under a will, alleged that a woman claiming a widow's share had never been legally married to testator. The woman had been divorced in New York by her first husband on the ground of adultery, presumably with testator. She and testator, both New York domiciliaries, had then been married in Pennsylvania to escape the New York law and decree forbidding her remarriage. Respondents attacked the validity of this marriage under the laws of both New York and Pennsylvania.

There was no difficulty with the objection under New York law, which the court held could not invalidate a marriage celebrated outside of the state. ${ }^{25}$ But in determining the validity of the marriage under the law of Pennsylvania the court had more than a little difficulty; for it seemed to be faced with a Pennsylvania statute which had never been applied to a case like the one at hand. The Pennsylvania statute prohibited an adulterer from marrying his or her paramour during the life of the complaining spouse, ${ }^{26}$ and the widow's first husband had been alive at the time of the contested marriage. However there was no Pennsylvania case found which had held the statute applicable to nondomiciliaries who had simply celebrated their marriage in Pennsylvania and then returned to their domicile. True enough, a famous Pennsylvania Supreme Court case had held that Pennsylvania domiciliaries could not evade the statute by marrying in another state and then returning to Pennsylvania to live. ${ }^{27} \mathrm{But}$

23a For the basic analysis of conflict-of-laws decisions in terms of the policy and interests of the states involved see Currie, Married Women's Contracts: A Study in Conflicts-of-Law Method, 25 U. of Chi. L. Rev. 227 (1958); Currie, Survival of Actions: Adjudication versus Automation in the Conflict of Laws, 10 Stan. L. Rev. 205 (1958); Currie, The Constitution and the Choice of Law: Governmental Interests and the Judicial Function, $26 \mathrm{U}$. of Chi. I. Rev. 9 (1958).

24192 Misc. 385, 79 N.Y.S.2d 404 (Surr.Ct., 1948).

25 "The law of New York forbidding remarriage of the divorced spouse during the life of the non-offending spouse is not effective beyond the territorial limits of this state, and a marriage contracted in another state by such a divorcee which is otherwise valid will be recognized as valid in New York." Id., at 388 and 407.

${ }^{26} \mathrm{~Pa}$. Stat. Ann. (Purdon, 1930) \$48-169. "The husband or wife, who shall have been guilty of the crime of adultery, shall not marry the person with whom the said crime was committed during the life of the former wife or husband. ..."

${ }^{27}$ In re Stull's Estate, 183 Pa. 625, 39 Atl. 16 (1898). 
this was a far cry from applying the statute to persons whose only connection with Pennsylvania was formal and fragmentary. The New York court grappled first with the general conflicts rule that a marriage invalid by the law of the state of its celebration was invalid everywhere; a rule which would not distinguish between domiciliaries and non-domiciliaries. But the court preferred $\mathrm{Cook}^{28}$ to Beale, ${ }^{29}$ and could not see the wisdom of applying the "domestic rule" of Pennsylvania when the reason for its application did not exist. Only if the marriage were "between persons domiciled within the State would [it] offend the public policy of the State so as to be held void. ..."30 Thus "since the parties to the marriage are not domiciled in the State of its celebration, and depart at once to live in the State of their domicile or intended domicile, a conflict-of-laws problem is presented to the State of celebration, and it should apply as its law in this situation, not its law for its domiciliaries, but its conflicts law, to wit, the law of the domicile of the parties." 31 The conflicts rule then led to New York, and since there was no New York public policy to void the marriage of an adulteress and her paramour the marriage was valid. ${ }^{32}$ The New York court, of course, was not ruling on a case under its own law but was interpreting Pennsylvania law in the absence of Pennsylvania decisions. Its ruling that Pennsylvania "should apply" was a ruling that Pennsylvania would apply its conflicts rule, rather than its domestic rule.

Yet the New York court was not to escape so easily-however sensible its solution might be. On a motion for re-argument it was discovered that there had been an unpublished opinion of a Pennsylvania lower court, the Court of Common Pleas of Susquehanna County, doing exactly what the New York court had decided could not be done- the statute had been applied to non-domiciliaries married in Pennsylvania. It was clear from the opinion in the case, Kalmbacher $v$. Kalmbacher, ${ }^{33}$ that the judge did not realize the possible significance of the parties being non-domiciliaries. ${ }^{34}$ Nevertheless, the New York

${ }^{28}$ Cook, The Logical and Legal Basis of the Conflict of Laws 442-56 (1942). "The only state which has a real interest, it would seem, is . . . the 'intended family domicile,' i.e., the state to which they intend to go and make their home, and to which ... they do go and settle down." Id., at 448.

292 Beale, The Conflict of Laws 674 (1935). "If by the law of the state where the marriage is celebrated a particular marriage is invalid, there is no marriage, whatever be the law of the domicile or of any other state."

${ }^{30}$ In re Palmer's Estate, 192 Misc. 385, 391, 79 N.Y.S.2d 404, 407 (Surr.Ct., 1948).

31 Ibid.

32 Id., at 392 and $410-11$. 3363 Pa. D. \& C. 195 (C.P., 1945).

34 The Pennsylvania court thought that In re Stull's Estate, 183 Pa. 625, 39 At1. 16 (1898), see also text at note 35 infra, which is clearly distinguishable from Kalmbacher, was controlling. The fact that the parties were foreign domiciliaries was never specifically mentioned, and in justifying the applicable statute the court said: "The legislature, in furtherance of public policy and good morals, may impose a disability upon its citizens restricting their right to contract a marriage." (Emphasis added.) 63 Pa. D. \& C. 195, 202 (C.P., 1945).

It may be that had the foreign domicile of the parties been stressed a different result would 
court was now faced with a decision of a Pennsylvania court applying to the facts at hand. But this was perplexing only for a moment; the New York court had little doubt which to choose between its interpretation of what the Pennsylvania court would do and what the lower Pennsylvania court had actually done. For,

... in a matter involving as fine a point as does the instant case, where the highest court of the State of Pennsylvania has not ruled upon the question, the Kalmbacher decision does not relieve this court of its responsibility to apply the correct principles of law as it sees them....

... As a matter of principle this court believes that its said decision is correct and that the law of the domicile of the parties is the law which Pennsylvania should, and presumably will, apply as its conflicts law in this situation. ${ }^{35}$

Thus here was a state court applying foreign law with a vengeance; its underlying rationale as simple as it is extreme-that in the absence of a holding on point from the highest court of the foreign state the forum has the widest latitude in determining the content of the foreign law. But clearly the determination here accorded with the policy and interest of the forum. Through all the. court's intellectual by-paths the motive is clear: to protect citizens of the forum from the effect of an unjust foreign decision.

\section{III}

But the peculiar effect of Kalmbacher has also reached the federal courts; and the reaction of the federal court illustrates the way in which it would be bound by a state court's interpretation of foreign law. In Lembcke v. United States, ${ }^{36}$ the Court of Appeals for the Second Circuit had to determine whether a claimant under a National Service Life Insurance Policy was a "widow" so as to be in the permissible class of beneficiaries. The government contended that claimant's marriage to the deceased violated the same Pennsylvania statute involved in Palmer and Kalmbacher. Again claimant and deceased were domiciliaries of New York, who had been divorced in New York by their respective spouses for adultery and had then been married in Pennsylvania. Swan, J., writing for the court, argued persuasively from the statutory history that the Pennsylvania statute should apply only to Pennsylvania residents divorced in Pennsylvania. ${ }^{37}$

have been reached; for the court was reluctant to void the marriage, and seemed to be reaching for a way out. "It might seem improper to permit petitioner to take advantage of his own wrong but a reasonable evaluation of the interest of the Commonwealth in the preservation of good morals and public welfare with reference to marriage as an institution far outweighs any misgiving on this feature of the case." Id., at 205.

${ }^{35}$ In re Palmer's Estate, 193 Misc. 411, 413-14, 82 N.Y.S.2d 818, 821 (Surr.Ct., 1948) (Emphasis added.)

${ }^{36} 181$ F.2d 703 (C.A.2d, 1950).

${ }^{37}$ Id., at 705 . 
But once again Kalmbacher raised an obstacle-one which could not be hurdled with the ease displayed by the New York court.

The court first recognized that if the case were based on diversity of citizenship and the federal court one of Pennsylvania, then there would be no way at all for the court to avoid Kalmbacher, even though the federal court was as convinced as the New York court that that decision was clearly wrong. "In a diversity case the federal court must follow the decision of a state trial court, absent higher state authority, because where that is the basis of jurisdiction it is inadmissible that there should be one rule of state law for litigants in the state courts and another for litigants who bring the same question before the courts sitting within the state." 38 On the other hand, if the case were based on diversity of citizenship, and the court were sitting in New York, it would then have to apply the conflicts law of New York. ${ }^{39}$ This would mean, of course, that In re Palmer's Estate ${ }^{40}$ would become the governing precedent, since it embodied the New York conflicts rule in the situation, and the New York view of Pennsylvania law would be the view of Pennsylvania law adopted by the federal court.4

Thus only in a case in which the federal court is not within the Erie doctrine in interpreting state law can the court escape the confines of the law and policy of the state in which it sits. The state court may use with great freedom the uncertainty of foreign law as a device; but a device with a purpose. When an archaic choice of law rule calls for the application of the law of the place of the tort, but contacts and policy rationally call for the law of the forum, then the forum may use the device to serve its own interest. When the validity of a marriage involved a policy of the forum, and its citizens are affected, then the court of forum may plead uncertainty of the foreign law, which might otherwise mechanically have been applied, to achieve a desired result.

When a federal court in a diversity case is faced with the problem of interpreting foreign law it is then not left without guides. The federal court does not merely have to guess what interpretation the court of the state in which it sits would make. If there is an interpretation which advances the interests of the state, then past behavior points to that interpretation as the one which most likely would have been made.

${ }^{38}$ Lembcke v. United States, 181 F.2d 703, 707 (C.A.2d, 1950).

${ }^{39}$ Id., at 706.

10192 Miisc. 385, 79 N.Y.S.2d 404 (Surr.Ct., 1948).

11 However the jurisdiction of the court in Lembcke did not rest on diversity but rather on the existence of a federal question. Therefore, "we believe the federal court has somewhat more freedom to differ with the decision of a single trial judge in a state court, although we confess that no decision on this point has been found." Lembcke v. United States, 181 F.2d 703, 707 (C.A.2d, 1950). 